\title{
Urgensi Teori Hierarki Kebutuhan Maslow Dalam Mengatasi Prokrastinasi Akademik Di Kalangan Mahasiswa
}

\author{
Muhibbin1, Marfuatun' \\ UIN Sunan Kalijaga Yogykarta ${ }^{1}$, Universitas Hamzanwadi ${ }^{2}$ \\ E-mail: ibinmuhib96@gmail.com¹, marfuatun.bkhamzanwadi@gmail.com²
}

Received: November 2020

Accepted: November 2020

Online Published: Desember 2020

\begin{abstract}
This paper aims to examine Abraham Maslow's hierarchical theory of needs and academic procrastination behavior, how to implement the hierarchy of needs theory as a solution to overcome academic procrastination behavior among students. the implications of Maslow's hierarchy of needs theory in the learning process. This research is a type of library research, (Reseaceh library). Data collection techniques used by researchers to collect data using documentation methods and one data source, namely secondary data sources. For data analysis using content analysis techniques (content analysis). The results of the research are: the hierarchy of needs theory is a theory of multilevel needs while academic procrastination is the lack of fulfillment of student responsibilities related to timely in the educational process. The implementation of the hierarchy of needs theory as a solution to overcome academic procrastination behavior among students so that physiological needs, security, feelings of love, respect and self-actualization of students can be fulfilled by fulfilling these five needs, student academic procrastination behavior can be overcome and the implications can stimulate students to take new opportunities. to improve themselves and, as a result, to improve their current achievements. It can also have a positive impact on them towards a better direction, for growth and provide benefits for themselves in the future.
\end{abstract}

\section{Keywords: Maslow's Hierarchy of Needs Theory, Academic Procrastination}

\begin{abstract}
Abstrak
Tulisan ini bertujuan untuk mengkaji tentang teori hirarki kebutuhan Abraham Maslow dan prilaku prokrastinasi akademik, bagaimana implemetasi dari teori hirarki kebutuan sebagai solusi untuk mengatasi perilaku prokrastinasi akdemik dikalangan mahasiswa. implikasiteori hirarki kebutuhan Maslow dalam proses pembelajaran. Penelitian ini merupakan jenis penelitian kepustakaan, (library Reseaceh). Teknik pengumpulan data yang digunakan peneliti untuk mengumpulkan data menggunakan metode dokumentasi serta satu sumber data yaitu sumber data skunder. Untuk analisis data menggunakan teknik analisis isi (conten analysis). Hasil penelitian berupa: teori hirarki kebutuhan merupakan suatu teori tentang kebutuhan bertingkat sedangkan prokrastinasi akdemik adalah kurangya pemenuhan tanggungjawab mahasiswa terkait tepat waktu dalam proses pendidikan. implemetasi dari teori hirarki kebutuan sebagai solusi untuk mengatasi perilaku prokrastinasi akdemik dikalangan sehingga kebutuhan fisiologis, rasa aman, rasa dicintai, dihargai dan aktulisaisi diri mahasiswa dapat terpenuhi dengan terpenuhinya kelima kebutuhan tersebut prilaku prokrastinasi akdemik mahasiswa dapat teratasi serta implikasinya dapat merangsang mahasiswa untuk mengambil peluang baru untuk meningkatkan kualitas diri mereka sendiri dan, sebagai hasilnya, meningkatkan prestasi mereka saat ini. Itu juga dapat memberikan dampak positif bagi mereka menuju ke arah yang lebih baik, untuk pertumbuhan dan memberi manfaat untuk dirinya di masa depan.
\end{abstract}

Kata Kunci: Teori Hirarki Kebutuhan Maslow, Prokrastinasi Akademik 


\section{PENDAHULUAN}

Pendidikan adalah suatu bentuk usaha yang dilakuakan agar tercapainya prestasi belajar yang bertujuan untuk terciptanya manusia yang berkualitas dan berdaya saing. Bagi seorang mahasiswa tentu saja mempunyai begitu banyak tugas baik tugas yang berkaitan dengan akademik ataupun non-akademik. Maka dari pada itu, setiap mahasiswa memiliki keharusan untuk dapat mengerjakan tugas-tugas tersebut dengan sebaik mungkin. Salah satu dari tugas menjadi seorang mahasiswa adalah memproleh prestasi terbaik yang dapat dibuktikan melalui nilai yang telah didapatkan setelah melewati proses pendidikan.

Namun fakta dilapangan menunjukkan bahwa problem yang sering kali dihadapi mahasiswa pada bidang akademik seperti biaya pendidikan, fasilitas belajar yang tidak memadai, jarak rumah yang jauh dengan kampus, pergaulan dengan teman sebaya, dan stres. Selain itu problem yang dihadapi mahasiswa pada bidang nonakademik adalah kurang menguasai cara belajar secara mandiri, kurang bisa memahami bahan perkuliahan dan materi literatur, kurang mampu manajemen waktu, motivasi belajar yang kurang, kesalahan dalam memilih jurusan, memiliki hubungan dengan dosen kurang baik, dan sebagainya.

Adapun beberapa tugas yang biasa sekali diberikan kepada mahasiswa antara lain tugas kelompok seperti pembuatan makalah yang nantinya akan dipersentasikan didepan kelas, membaca buku perkuliahan sebagai persiapan pada setiap kali pertemuan, tugas individu berupa mind mapping atau resume materi perkuliahan, praktikum, dan lain sebagainya. Tugas-tugas yang seperti itu sering kali dirasakan berat oleh mahasiswa sehingga memberiakan efek buruk pada pencapaian prestasinya. Penurunan prestasi tersebut disebapkan karena mahasiswa sering menunda dalam menyelesaian tugas-tugasnya. Terkait dengan problem ini maka yang sering dilakukan oleh para dosen sebagai jalan keluar untuk mengatasi problem tersebut yaitu dengan memberikan tugas kembali kepada mahasiswa yang bersangkutan dengan tujuan agar tidak mengulangi kembali kebiasannya dan supaya merasa termotivasi untuk mengumpulkan tugas tepat waktu.

Namun apa yang terjadi, malah yang terjadi adalah sebaliknya bahkan hal tersebut melahirkan problem baru seperti mahasiswa sering membolos, tidak masuk kuliah atau pura-pura sakit dan lain sebagainya. Oleh karena itu, dibutuhkan cara lain sebagai solusi dari problem yang berhubungan dengan prokrastinasi akademik yang dilakukan oleh mahasiswa. Seseorang yang mengalami kesulitan dalam melakukan sesuatu sesuai batas waktu yang telah ditetapkan, akan mengalami keterlambatan, menyiapkan sesuatu tidak maksimal, berlebihan dan bahkan tidak jarang bagi 
mahasiswa mengalami kegagalan dalam menyelesaikan tugas yang telah diberikan dosen. Prokrastinasi merupakan suatu perilaku yang paling sering menjangkiti kalangan remaja ataupun orang dewasa terutama dikalangan para mahasiswa. Lebih jelasnya prokrastianasi adalah perilaku atau sikap seseorang yang tidak bisa dikendalikan dalam mengerjakan suatu tugas atau pekerjaan (Putr,2019: 49-56).

Isltilah dari prokrastinasi ini berasal dari bahasa latin yaitu procrastination yang memiliki arti menunda atau menagguhkan suatu tugas atau pekerjaan sampai pada hari berikutnya dan pada akhirnya pekerjaan tersebut belum terselesaikan (Rahmatia, Halim, 2015:133-149).Steel mengemukakan bahwasanya prokrastinasi adalah kesengajaan seorang individu menunda suatu yang ingin ia lakukan meskipun seseorang itu tau bahwa hal yang dilakukan tersebut akan berdampak buruk bagi dirinya (Damri, Engkizar, Anwar : 74-95) Sedangkan Knaus memberi penjelasan prokrastinasi merupakan kebiasaan menunda melakukan sebuah kegiatan yang penting dan tidak mengerjakan tugas dengan tepat waktu sehingga hal tersebut dapat merugiakan diri (Kurniawa,2017).

Ellis dan Knaus mengungkapkan bahwasanya 70\% dari mahasiswa telah melakukan prokrastinasi akademik pada makna yang luas ditandai dengan kelambanan dalam mengumpulkan tugas, terlambat hadiri dalam perkuliahan, dan lain sebagainya. Menurut Djamarah masih banyak mahasiswa yang mengeluh dikarenakan mereka tidak bisa manajemen waktu yang ia miliki dengan baik, seperti kapan harus memulai dan mengerjakan tugas yang telkah diberikan oleh dosen (Fatimah, 2018). Maka solusi yang dapat dilakukan untuk mengatasi prokrastinasi akademik adalah mecari terlebih dahulu apa penyebap terjadinya sehingga dapat diketahui kebutuhan apa yang belum bisa terpenuhi. Menurut penulis kebutuhan merupakan sesuatu yang diperlukan oleh setiap individu dalam waktu tertentu baik yang berupa kebutuhan pisikologis ataupun kebutuhan sosial.

Dari perbedaan kebutuhan tersebut maka seorang dosen atau pendidik dapat memehami dan mencari solusi mengurangi perilaku prokrastinasi akademik pada mata kuliah yang diampunya yaitu dengan cara menerapkan teori hierarki kebutuhan Abraham Maslow dengan harapan agar proses pembelajaran yang dilakukan dapat berjalan dengan optimal dan mahasiswa memiliki perilaku yang produktif. Maka penlitian ini dilakukan penting untuk membantu para pendidik dalam mengatasi permaslahan pendidikan terutama yang berkaitan dengan masalah prokrastinasi akademik yang saat ini masih sering terjadi di dunia pendidikan.Penelitian ini bertujuan untuk, mengkaji tentang teori hirarki kebutuhan Abraham Maslow dan prilaku prokrastinasi akademik, bagaimana implemetasi dari teori hirarki kebutuan 
sebagai solusi untuk mengatasi perilaku prokrastinasi akdemik dikalangan mahasiswa. bagaimana implikasiteori hirarki kebutuhan Maslow dalam prosespembelajaran.

\section{METODE PENELITIAN}

Penelitian ini merupakan penelitan kepustakaan (library reseaceh) dalam hal ini peneliti menggunakan dokumen-dokumen atau teks-teks tertentu yang bekaitan dengan tema penelitian sebagai objek kajian (Ardana, dkk, 2001:96). Adapun teknik pengumpulan data yang digunakan peneliti untuk mengumpulkan data menggunakan metode dokumentasi yaitu menelusuri berbagai sumber seperti jurnal, artikel, buku dan catatan tertertentu yang berkaitan dengan tema penelitian. Dalam hal ini peneliti hanya menggunakan satu teknik pengumpulan data serta satu sumber data yaitu sumber data skunder baik cetak maupun eltronik. Selanjunya untuk teknik analisis data yang digunakan peneliti dalam penelitian ini menggunakan analisis isi (conten analysis).

\section{HASIL DAN PEMBAHASAN}

\section{Teori Hirarki Hebutuhan Abraham Maslow dan Prokrastinasi Akademik}

Teori hirarki kebutuhan merupakan suatu teori tentang kebutuhan manusia yang memiliki tingkatan sesuai dengan yang telah diungkapkan oleh Abraham Maslow. Hirarki kebutuhan merupakan teori tentang motif manusia dengan cara mengklasifikasikan kebutuhan dasar manusia dalam suatu hierarki, dan teori motivasi manusia yang dihubungkan kebutuhan-kebutuhan ini dengan perilaku umum (Bouzenita, Boulanouar, 2016:59-81). Menurut maslow manusia akan terdorong untuk memenuhi kebutuhan yang paling dibutuhkan sesuai dengan waktu, keadaan, dan pengalaman dirinya dalam mengikuti suatu hirarki (Artaya). Selanjutnya menurut teori Maslow juga, dijelaskan bahwa seseorang tidak akan dapat memenuhi kebutuhan kedua apabila kebutuhan yang pertama belum terpenuhi atau yang ketiga sampai yang kedua dapat terpenuhi, dan seterusnya (Jerome, 2013:39-40). Karena kebutuhan dasar merupakan kebutuhan yang paling utama dari kebutuhan lain dan perlu untuk dipenuhi sebab apabila kebutuhan dasar tidak tepenuhi maka lainya tidak dapat dipenuhi.

Maslow mengolongkan kebutuhan manusia menjadi lima kebutuhan dasar yang dijelaskan dalam bentuk piramida tingaktan yang dimulai dari kebutuhan fisiologis, keamanan (safety), dimiliki dan cinta (belonging and love), harga diri (self esteem), dan kebutuhan aktualisasi diri (Ginting, 2018:220-233).

a) Kebutuhan Fisiologis

Kebutuhan ini merupakan kebutuahan yang termasuk kedalam kebutuhan primer untuk memenuhi pisikologis dan biologis manusia yang terdiri 
dari kebutuhan akan oksigen, makanan, air, dan suhu tubuh yang relatif konstan. Menurut maslow kebutuhan fisiologis merupakan suatu kebutuhan yang sangat penting terpenuhi. Kebutuhan fisiologia inilah yang lebih utama untuk dicari oleh setiap orang dalam mencari kepuasan.Apabila kebutuan fisiologis telah terpenuhi maka akan naik ke tingkatan kebutuhan selanjutnya yaitu kebutuhan rasa aman.

b) Kebutuhan keamanan (safety)

Kebutuhan ini berupa kebutuhan akan rasa keamanan, kemantapan, ketergantungan, perlindungan, bebas dari rasa takut, cemas dan kekalutan, dan lain sebgainya. Maslow menyatakan bahwa orang berusaha mengatasi perasaan kesepian dan keterasingan. Ini melibatkan memberi dan menerima cinta, kasih sayang dan rasa memiliki. Kebutuhan seperti ini dapat diwujudkan oleh seorang pendidik atau dosen melalui pembelajaran demokratis, yaitu mencoba berbagai latihan belajar tampa adaya rasa takut atau bulyy dari pihak dosen ataupun masiswa lain ketika mahsiswa mengakui bahwa ia belum menguasai materi pelajaran.

c) Kebutuhan dimiliki dan cinta (belonging and love)

Kebutuhan akan keinginan untuk diterima keberadaan dirinya dalam suatu lingkungan tampa membedakan kondisi fisik, ras ataupun perbedaan kehidupan social. Yang dimana jika kebutuhan ini dapat terpenuhi maka akan menumbuhkan sikap kepercayaan diri yang tinggi sehingga dirinya merasamempunyai. kesempatan sama untuk maju dan akan mendorong seseorang tersebut untuk terlibat pada semua kegiatan sesuai dengan minat dan bakat yang ia miliki.

d) Kebutuhan harga diri (self esteem)

Adalah kebutuhan individu untuk diakui kebradanya oleh pihak lain. kebutuhan ini dapa direlisasikan oleh pendidik atau dosen dengan cara member dukungan kepada masiswanya mengutarakan pendapatnya apabila tujuan pembelajaran tidak sesuai dengan yang di inginkan. Oleh sebab itu keradaan mahsiswa perlu diakui dan wajib direalisaikan karena semakin tinggi pengakuan terhadap keberadan mahasiswa tersebut maka semakin tinggi pula kebutuhanya untuk menunjukkan prestasinya.

e) Kebutuhan aktualisasi diri

Kebutuhan ini juga disebut dengan kebutuhan terhadap perwujudan diri. Kebutuhan ini biasanya dapat terpenuhi setelah kebutuhan fisiologis, rasa aman, kasih sayang dan pengakuan dari orang lain terpenuhi (Susanto, Lestari, 2018:184-202).Maslow menggambarkan aktualisasi diri sebagai kebutuhan seseorang untuk menjadi dan melakukan apa yang orang itu "dilahirkan untuk 
melakukannya. Misalnya seorang musisi harus mebuat musik, seorang seniman harus dapat membuat lukisan, dan seorang penyair harus menulis.

Kebutuhan-kebutuhan ini membuat diri mereka merasa tanda-tanda gelisah atau tidak merasa tenag. Orang itu merasa gelisah, tegang, ada sesuatu yang kurang, singkatnya, gelisah. Jika seseorang lapar, tidak merasa aman, tidak dicintai atau diterima, atau kurang percaya diri, sangat mudah untuk mengetahui apa yang membuat orang itu gelisah. Namun, tidak selalu jelas apa yang diinginkan seseorang ketika ada kebutuhan untuk aktualisasi diri. Kelima kebutuhan diatas dapat digambarkan dalam bentuk piramida kebutuhan seperti pada gambar di bawah ini:

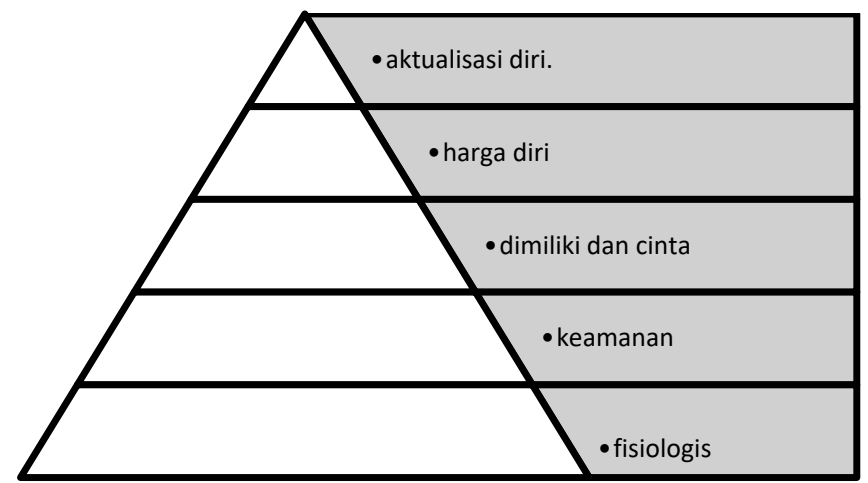

Gambar 1. Piramida kebutuhan menurut Maslow

Gambar diatas mengambarkan bahwa dalam konteks belajar, tingkatan aktualisasi diri merupakan kebutuhan tertinggi yang nantinya diwujudkan melalui prestasi belajar yang dilakukan oleh mahasiswa. Untuk mencapai hal tersebut maka perlu terpenuhi kebutuhan-kebutuhan dasar yang akan menunjang terwujudnya kebutuhan tertinggi yaitu aktualisasi yang berupa prsetasi belajar. Apa bila kita mengharapkan mahasiswa yang berprestasi maka empat kebutuhan dasar tersebut harus terealisasikan. Sebaliknya apabila empat kebutuhan dasar maka terpenuhi maka kebutuhan aktualisasi atau prestasi belajar tidak akan terpenuhi. Adapun kelebihan dan kekurangan dari teori ini adalah sebagai berikut:

a. Kelebihan teori hirarki kebutuhan

1) Memberikan informasi bahwa kebutuhan manusia bersifat materil dan non materil dan memiliki tingkatan.

2) Mengetahui bahwa seseorang mengerjakan tugas atau pekerjaannya bertujuan untuk memenuhi kebutuhanya.

3) Kebutuhan manusia memiliki jenjang sesuai dengan kedudukan ataupun social ekonominya. 
4) Dapat memudahkan individu dalam memberikan motivasi yang tepat kepada orang lain untuk memberikan rangsangan agar semangat dalam mengerjakan tugas dan pekerjanya.

b. Kekurangan teori hirarki kebutuhan

1) Menurut teori ini bahwa kebutuhan manusia itu memiliki tingkatan namu pada kenyataanya manusia kebutuhan tersebut bisa trpenuhi sekaligus dan kebutuhan manusia itu merupakan siklus yang terus berulang-ulang.

2) Teori ini belum pernah dilakukan uji coba kebenaranya secara empiris karena pada dasarnya maslow mengembangkan teorinya sesuai pengalamnya. (Sari, Dwiarti, 2018).

Menurut pendapat Fiore bahwa prokrastinasi secara etiologis berasal dari bahasa latin yaitu dari kata pro atau forwad yang berarti maju, dan crastinus atau tomorrow yang memiliki arti hari esok. Sedangkan etimologis prokrastinasi merupakan suatu mekanisme dalam mengatasi rasa cemas yang berkaitan dengan bagaimana cara dalam memulai atau mengerjakan suatu pekerjaan yang berkaitan dengan pengambilan keputusan (Fernando, Rahman, 2016). Prokrastinasi akadmik ini dinyatakan sebagai kurangya pemenuhan tanggungjawab mahasiswa terkait tepat waktu dalam proses pendidikan. (Demir, Kutlu, 2018: 315-332).

Fenomena ini berkaitan dengan masalah pengaturan diri, pengalaman, dan persepsi individu ketika berusaha dalam mencapai tujuan akademis, profesional, terkait kehidupan, atau lainnya (Aydoğan, Akbarov, 2018:3-4). Beberapa penelitian menemukan bahwa mahasiswa yang umurnya lebih muda cenderung lebih sering menunda-nunda daripada mahasiswa yang lebih tua. Hal ini mencerminkan tingkat kematangan mahasiwa muda dan ketidakmampuan mereka untuk dapat bertanggung jawab penuh atas proses pembelajaran mereka (Zacks, Hen, 2018). Atau bisa juga karena proses studi mereka yang terlalu lama sehingga menyebapkan mereka menunda untuk menyelesaikan tugas mereka.

Menurut pendapat Schouwenburg dalam Ferrari mengungkapkan bahwa indicator terjadinya prokrastinasi akademik antara lain: 1) Penundaan dalam mengerjakan tugas 2) lamban dan terlambat dalam mengerjakan tugas akdemik 3) Ketidaksesuaian antara rencana dengan performansi aktual, 4) melakukan kegiatan lain yang menurutnya lebih menarik. Sedangkan menurut pendapat Friend yang dikutip Timpe bahwa prokrastinasi disebapkan oleh beberapa faktor diantaranya sebagai beriku:1) tidak kurangya kepercaya diri 2) toleransi frustasi yang rendah 3) menuntut untuk menjdi sempurna 4) jenis kelamin yang berbeda 5) memiliki pandangan patalistik.

Dalam penelitian-penelitan sebelumnya menunjukkan bahwa prokrastinasi ini disebapkan karena factor-faktor seperti kurangnya regulasi diri, motivasi yang 
kurang, pusat kendali diri dari luar, prfeksionis, kurangnya bisa mengatur waktu, kurangnya kontol diri, (self control), self consciuous, rendahnya self esteem, self efficacy, dan kecemasan social.sedangkan Burka dan Yuen, mgungkapkan bahwa penyebap prokrastinasidisebapkan karena beberapa hal seperti: rasa cemas terhadap evaluasi yang akan diberikan, mengalami kesulitan dalam pengambilan sebuah keputusan, meberontakan terhadap kontrol dari figur otoritas, kurang bimbingan, standar pencapaian yang terlalu tinggi (Fernando, Rahman,2016).

\section{Implementasi Teori Maslow Dalam Mengurangi Prokrastinasi Akademik}

Untuk mencipatakan proses pembelajaran yang efektif, maka seorang pendidik atau dosen harus mampu memahami konsep motivasi secara menyeluruh. Motivasi merupakan keadaan mental yang mampu mendorong seseorang untuk melakukan sesuatu dan memberikan kekuatan yang mengarah pada pencapaian kebutuhan, member kepuasan, dan mengurangi ketidak seimbangan (Setiawan, Miftahussalam, 2016:36).

Seperti yang dijelaskan oleh Abdorrahkhman Ginttings dalam bukunya bahwa kuat atau lemahnya partisipasi yang di lakukan oleh mahasiswa dalam proses belajar mengajar tergantung pada seberapa kuat motivasinya dalam belajar. (Ginttings, 2008:87). Teori motivasi Maslow dapat terapkan untuk membantu seorang pendidik dalam menetukan metode yang sesuai dalam memotivasi mahasiswanya. karena perbedaan motivasi akan memberi dampak berbeda pada tujuan individual, yang nantinya akan menganggu tercapinya tujuan dari proses pembelajaran itu sendiri.

Dalam kontek pendidikan teori Maslow tentang hirarki kebutuhan dapat menjadi rujukan ilmiah dalam membangun motivasi mahasiswa dalam proses belajar. Terpenuhinya kebutuhan-kebutuhan tersebut akan mendorong mahasiswa untuk mengerjakan tugas atau pekerjaannya secara maksimal, hal ini sangat penting karena apabila kebutuhan dasar mahasiswa tidak terpenuhi maka maka akan berdampak buru prestasi akademik masiswa. Untuk mewujudkan hal tersebut maka perlu dipastikan bahwa kelima kebutuhan tersebut harus terpenuhi oleh seorang pendidik.Menurut Mendari, 2010 dalam Fatimah dapat diterapkan dalam proses pendidikan antara lain sebagai berikut:

a. Kebutuhan Fisiologis

Dalam rangka pemenuhan kebutuhan fisiologis ini, pihak kampus harus menyediakan berbagai fasilitas yang membantu mahasiswa dalam memenuhi kebutuhan fisiknya antara: kantin, ruang kelas yang bersih nyaman dan aman, toilet, musollah serta lingkungan belajar yang mendukung (Fatimah,2018:36).

b. Kebutuhan keamanan 
Untuk memenuhi kebutuhan rasa aman (Safety) mahasiswa dapat dilakukan dengan berbagai cara seperti: Memepersiapkan program pemebelajaran yang baik mulai dari materi pelajaran dan media pembelajaran yang mendukung jalanya proses belajara. Dosen yang bersikap humoris. Dosen dapat mengarahkan mahasiswanya saat berada di kelas. Dosen dapat menerapkan disiplin serta labih banyak memberiakan rewad berupa pujian daripada hukuman pada mahasiswa (Fatimah,2018:36).

c. Kebutuhan akan dimiliki dan dicintai

Dalam dunia akdemik kebutuhan ini terbagi menjadi dua antaralain:

1. Hubungan mahasiswa dan dosen

Dalam pemenuhan kebutuhan akan dimiliki dan dicintai ini, dosen diharuskan bersikap empati kepada mahsiswa, memberikan perhatian, sabar, bersikap adil, terbuka, menjadi pendengar yang baik untuk mahsiswanya. Menjadi orang yang dapat diandalkan, menghargai pendapat, pemikiran dan keputusan mahasiswanya.

2. Hubungan antar sesama mahasiswa

Hal ini dapat dilakukan oleh dosen dengan mencoba menerapkan model pembelajaran yang memungkin mahasiswa untuk berkerja sama sehingga terciptanaya sikap saling percaya antara mahasiswa. Selain itu mahasiswa juga dapat membentuk himpunan mahasiswa jurusan ataupun lain sebagainya (Fatimah,2018:36-37).

d. Kebutuhan harga diri

Dalam hal ini kebutuhan akan harga diri ini terbagi menjadi dua jenis yaitu:

1. Menghargai diri sendiri seperti penguasaan diri, kompetensi diri, prestasi, percayadiri, kemandirian dan bebas.

2. Dihargai oleh orang lain seperti status,ketenaran, dihormati, apresiasi dan diterima (Fatimah,2018:37).

e. Kebutuhan aktualisasi diri

Kebutuhan ini akan terpenuhi secara maksimal apabila individu mampu untuk menggunakan semua potensi, bakat setra kemampuan yang dimilikinya. Individu yang telah mncapai aktualisasi diri ini menjadi manusia yang utuh dan akan mendapat kepuasan dari kebutuhan-kebutuhan yang orang lain tidak menyadari akanhal itu. (Fatimah,2018:37).

\section{Implikasi Teori Hirarki Kebutuhan Maslow Dalam Proses Pembelajaran}

Dilihat dari sudut pandang teori hirarki kebutuhan ini, lingkungan pembelajaran merupakan hasil dari kebutuhan belajar, dan perpaduan berbagai kebutunahan serta harapan, dan pengalaman diri (Hermawan,2009:229). Adapun implikasi dari teori hirarki kebutuhan ini dalam proses pembelajaran antaralain sebagai berikut: 
1. Kebutuhan Fisiologis, kebutuhan ini dapat apabila seorang dosen memberiakan kompensasi kepada mahasiswanya berbentuk tugas susulan apabila mahasiswanya tersebut telat mengumpulkan tugasnya.

2. Dapat memenuhi kebutuhan akan rasa aman (safety) hal ini dapat dilakukan dengan melalui pembelajaran demokratis.

3. Dapat memenuhi kebutuhan akan rasa dimiliki dan cinta (belonging and love) kebutuhan ini dapat terpenuhi apabila seorang pendidik dapat mendorong siswanya untuk membangun sikap oktimis yang tinggi dan memiliki keyakianan bahwa ia memiliki kesepatan sama untuk maju dan akan mendorong sesorang tersebut untuk terlibat pada semua kegiatan sesuai dengan minat dan bakat yang ia miliki.

4. Kebutuhan harga diri (self esteem) kebutuhan ini dapat direlisasikan oleh pendidik atau dosen dengan cara memberi dukungan kepada masiswanya mengutarakan pendapatnya apabila tujuan pembelajaran tidak sesuai dengan yang diinginkan. Oleh sebab itu keradaan mahsiswa perlu diakui dan wajib direalisaikan karena semakin tinggi pengakuan terhadap keberadan mahasiswa tersebut maka semakin tinggi pula kebutuhanya untuk menunjukkan prestasinya. Apabila hal ini dilakukan maka mahsiswa tersebut merasa dihargai.

5. Kebutuhan aktualisasi diri. Kebutuhan ini biasanya dapat terpenuhi apabila kebutuhan fisiologis, rasa aman, kasih sayang dan pengakuan dari orang lain terpenuhi.

Hal semacam ini dapat merangsang mahasiswa untuk mengambil peluang baru untuk meningkatkan kualitas diri mereka sendiri dan, sebagai hasilnya, meningkatkan prestasi mereka saat ini. Itu juga dapat memberikan dampak positif bagi mereka menuju ke arah yang lebih baik, untuk pertumbuhan dan memberi manfaat untuk dirinya di masa depan.

\section{SIMPULAN}

Teori hirarki kebutuhan merupakan suatu teori tentang kebutuhan bertingkat sedangkan prokrastinasi akdemik adalah kurangya pemenuhan tanggungjawab mahasiswa terkait tepat waktu dalam proses pendidikan. implemetasi dari teori hirarki kebutuan sebagai solusi untuk mengatasi perilaku prokrastinasi sehingga kebutuhan fisiologis, rasa aman, rasa dicintai, dihargai dan aktulisaisi diri mahasiswa dapat terpenuhi dengan terpenuhinya kelima kebutuhan tersebut prilaku prokrastinasi akdemik mahasiswa dapat teratasi. Implikasinya dapat merangsang mahasiswa untuk mengambil peluang baru untuk meningkatkan kualitas diri mereka sendiri dan, sebagai hasilnya, meningkatkan prestasi mereka saat ini. Itu juga dapat memberikan dampak 
positif bagi mereka menuju ke arah yang lebih baik, untuk pertumbuhan dan memberi manfaat untuk dirinya di masa depan.

\section{UCAPAN TERIMA KASIH}

Penulis mengucap banyak terimakasih kepada semua pihak yang telah membantu dalam pelaksanaan penelitian ini UIN Sunan Kalijaga dan Universitas Hamzanwadi atas dukungannya sehingga peroses kajikan ini dapat terselesaikan tepat waktu. Serta pihakpihak lain yang tidak dapat saya sebutkan satu-persatu.

\section{DAFTAR PUSTAKA}

Ardana, dkk. (2001). Metodelogi Penelitan Pendidikan, Malang: UMM.

Artaya, I., P. (2015). Penerapan Teori Motivasi Hierarki Kebutuhan Abraham H. Maslow Dan Teori Pemeliharaan Herzberg Dalam Menciptakan Loyalitas Pekerja. Universitas Narotama, Fakultas Ekonomi Dan Bisnis, Jl. A.R. Hakim 51 Surabaya, 60117 Indonesia.

Aydoğan, H. \& Akbarov, A. (2018). A case study on academic procrastination in EFL setting in Turkey. Acta Didactica Napocensia, 11(3-4), 79-88, DOI: 10.24193/adn.11.3-4.6.

Bouzenita, I, A., Boulanouar, W, A. (2016). Maslow's Hierarchy Of Needs: An Islamic Critique. Intellectual Discourse, 24:1 59-81.

Damri, Engkizar, Anwar, F. (2017). Hubungan Self-Efficacy Dan Prokrastinasi Akademik Mahasiswa Dalam Menyelesaikan Tugas Perkuliahan, Jurnal Bimbingan Konseling, hlm. 74 - 95. DOI: http://dx.doi.org/10.22373/je.v3i1.1415

Demir, Y., Kutlu, M. (2018). Relationships Among Internet Addiction, Academic Motivation, Academic Procrastination And School Attachment In Adolescents. International Online Journal of Educational Sciences, 10 (5), 315-332. DOI: https://doi.org/10.15345/iojes.2018.05.020.

Fatimah, S. (2018). Menurunkan Prokrastinasi Akademik Melalui Penerapan Teori Hierarki Kebutuhan Maslow. Vol. 2, No. 1, Januari. DOI: https://doi.org/10.22460/q.v2i1p\%25p.713

Fernando, F., Rahman, K, 2016, Konsep Bimbingan Dan Konseling Islam Solution Focused Brief Therapy (SFBT) Untuk Membantu Menyembuhkan Perilaku Prokrastinasi Mahasiswa, Jurnal Edukasi Vol 2, Nomor 2, July. DOI: http://dx.doi.org/10.22373/je.v2i2.818

Ginting, A., P. (2018). Implementasi Teori Maslow Dan Peran Ganda Pekerja Wanita K3I Universitas Padajajaran. Jurnal Pekerjaan Sosial, Vol. 1 No: 3, Desember, Hal: 220 - 233. DOI : https://doi.org/10.24198/focus.v1i3.20498

Ginttings, Abdorrahkhman. (2008). Esnsi Praktis Belajar dan Pembelajaran, Bandung: Humaniora. 
Hermawan, S. (2009). Aplikasi Dan Pengaruh Pemikiran Abraham Maslow Pada Manajemen Bisnis, Humanisme Dan Pembelajaran. JAMBSP Vol. 5 No. 2 - Februari: 226- 234.

Jerome, N. (2013). Application Of The Maslow's Hierarchy Of Need Theory; Impacts And Implications On Organizational Culture, Human Resource And Employee's Performance. www.ijbmi.org Volume 2 Issue 3 || March. || PP.39-4

Kurniawa, E, D. (2017). Pengaruh Intensitas Bermain Game Online Terhadap Perilaku Prokrastinasi Akademik Pada Mahasiswa Bimbingan Dan Konseling Universitas PGRI Yogyakarta. Jurnal Konseling GUSJIGANG Vol. 3 No. 1 (Januari-Juni)

Noor, K. W., Qomariyah, U. (2019). Hierarki Kebutuhan Sebagai Dasar Refleksi Diri Tokoh Dalam Novel Pesantren Impian. JSI 8 (2). http://lib.unnes.ac.id/id/eprint/35567

Putri, S. N. (2019). Konseling Kelompok Dengan Terapi Realita Dalam Menurunkan Prokrastinasi Akademik, Konseli. Jurnal Bimbingan dan Konseling (E-Journal), 06 (1); 49-56. DOI: https://doi.org/10.24042/kons.v6i1.4195

Rahmatia, R., Rahman, H. N. (2015). Model Pengentasan Sikap Prokrastinasi Akademik (Studi Pengembangan Berbasis Cognitive Behavior Therapy. Jurnal Psikologi Pendidikan \& Konseling, Volume 1 Nomor 2 Desember , hlm 133- 149. DOI: https://doi.org/10.26858/jpkk.v1i2.1813

Sari, E., Dwiarti, R. (2018). Pendekatan Hierarki Abraham Maslow Pada Prestasi Kerja Karyawan Pt. Madubaru (Pg Madukismo) Yogyakarta, JPSB Vol.6 No.1. DOI: https://doi.org/10.26486/jpsb.v6i1.421

Setiawan, Jemmy, Miftahussalam, S. (2016). Problem Solver, Jakarta: PT Elex Media Komputindo Klompok Gramedia.

Susanto, H, N., Lestari, C. (2018). Problematika Pendidikan Islam Di Indonesia: Eksplorasi Teori Motivasi Abraham Maslow Dan David Mcclelland. Jurnal Pendidikan Islam, Vol. 3 No. 2, Desember, hlm. 184-202. DOI: https://doi.org/10.28918/jei.v3i2.1687

Zacks, S., Hen, M. (2018). Academic Interventions For Academic Procrastination: A Review of The Literature. Journal of Prevention \& Intervention in the Community, 46:2, 117-130, DOI: https://doi.org/10.1007/s10942-012-0148-6 